\title{
Evaluation of evaporation measuring methods for reference evapotranspiration within Greenhouse
}

\author{
E. Sujitha*1, K. Shanmugasundaram ${ }^{2}$ and G. Thiyagarajan ${ }^{3}$
}

${ }^{1}$ Institute of Agriculture, Tamil Nadu Agricultural University, Kulmulur, Trichy (T.N.) India

${ }^{2}$ Department of Basic Engineering and Applied Sciences, Agriculture Engineering College and Research Institute, Tamil Nadu Agricultural University, Kumulur, Trichy (T.N.) India

${ }^{3}$ Water Technology Centre, Tamil Nadu Agricultural University, Coimbatore (T.N.) India

\section{ARITCLE INFO}

Received : 28.01 .2020

Revised : 01.03 .2020

Accepted : 14.03 .2020

\section{KEY WORDS :}

Class A pan, Reduced $\operatorname{pan}_{20 \mathrm{~cm} \varnothing}$ Reduced pan ${ }_{60 \mathrm{~cm} \emptyset}$, Evapotranspiration, Linear regression
*Corresponding author:

Email : sujitha047@gmail.com

\begin{abstract}
Alternative methods for estimating reference evapotranspiration (ETo) within greenhouses are explored due to the large area occupied by a Class A pan. Based on the locations, the evapotranspiration difference between inside and outside greenhouse varies. Research results about what pan co-efficient $(\mathrm{Kp})$ should be utilized inside the greenhouse are not conclusive. Therefore the main objective of the work was to compare ETo calculated by various methods within and outside a greenhouse. A Class A pan (CAPi), a reduced pan $\left(\mathrm{RPi}_{60 \mathrm{~cm} \varnothing}\right)$ and a reduced pan $\left(\mathrm{RPi}_{20 \mathrm{~cm} \varnothing}\right)$ were installed inside a greenhouse, and another Class A pan (CAPo) was installed outside. ETo estimates, obtained by $\mathrm{CAPi}, \mathrm{RPi}_{60 \mathrm{~cm} \varnothing}$ and $\mathrm{RPi}_{20 \mathrm{~cm} \varnothing}$ were 54 per cent, 57 per cent and 59 per cent of those estimated by CAPo, respectively. A simple linear regression showed positive coefficients $\mathrm{R}=0.76$ for the $\mathrm{CAP}_{\mathrm{o}} \times \mathrm{CAP}_{\mathrm{i}}, \mathrm{R}=0.96$ for the $\mathrm{CAP}_{\mathrm{i}}$ and the $\mathrm{RPi}_{60 \mathrm{~cm} \varnothing}, \mathrm{R}=0.98$ for the CAPi and the $\mathrm{RPi}_{20 \mathrm{~cm} \varnothing}$. The study concluded that it is possible to use reduced pans to estimate the ETo inside the greenhouse and replacement of reduced pan would increase the space available for cultivation in the greenhouse.
\end{abstract}

How to view point the article : Sujitha, E., Shanmugasundaram, K. and Thiyagarajan, G. (2020). Evaluation of evaporation measuring methods for reference evapotranspiration within Greenhouse. Internat. J. Plant Protec., 13(1) : 62-66, DOI : 10.15740/HAS/IJPP/13.1/62-66, Copyright@ 2020: Hind Agri-Horticultural Society. 